ISMC 2021

$16^{\text {th }}$ International Strategic Management Conference

\title{
THE IMPACT OF INDIVIDUAL CULTURAL VALUES AND RELIGIOSITY ON FINANCIAL PREFERENCES
}

\author{
Selim Aren (a)*, Hatice Nayman Hamamc1 (b) \\ *Corresponding author
}

(a) Yıldız Technical University, Business Department, İstanbul, Turkey, saren@yildiz.edu.tr (b) Yıldız Technical University, Business Department, İstanbul, Turkey, hnayman@yildiz.edu.tr

\begin{abstract}
In this study, the effect of religiosity and culture on the preference of financial instruments with interest and non-interest was investigated. For this purpose, 1934 people from Turkey was reached through an online survey and data were collected with convenience sampling. Individual preferences were investigated when interest-bearing and interest-free financial instruments had equal returns and interestfree financial instruments had lower returns. Individual cultural values, religiosity and negative opinions on interest were included as determinants of these choices. Individual cultural values were taken in five dimensions, and it was determined that each dimension has positive correlations with both religiosity and negative opinion on interest. The tendency to financial instruments with or without interest was designed as a three-dimensional categorical variable: (1) those who do not want interest return under any circumstances, (2) those who prefer an interest-free investment instrument when the return of an interestfree investment instrument and an interest-bearing investment instrument is equal and (3) those who always prefer an investment instrument with an interest return, and the effect of independent variables were investigated using discriminant analysis. Accordingly, it was determined that three dimensions of individual cultural values - collectivism, masculinity, power distance, and religiosity as well as negative opinion on interest are significant variables in the correct classification. In addition, those between the ages of 31-50 and those with undergraduate and graduate education have a higher tendency toward interest-bearing financial instruments.
\end{abstract}

2357-1330 @ 2021 Published by European Publisher.

Keywords: Financial preferences, financial instruments, interest, individual cultural values, religiosity 


\section{Introduction}

Religion and culture are two basic characteristics of individuals. Religion is a belief system that shows both the right and wrong (Mansori et al., 2020). Culture is also a value that indicates what is right and what is wrong (Akremi \& Smaoui, 2015; Ashraf et al., 2016; Ashraf \& Arshad, 2017; Donohue, 2020). Both affect decisions and behavior. Various studies have investigated the effect of religiosity on financial decisions (Al Balushi et al., 2018; Bhuian et al., 2018; Mansori et al., 2020; Usman et al., 2017). However, the degree of this effect varies according to the level of commitment to people's beliefs (Zakaria et al., 2020). In other words, the religiosity levels of people make a difference in their preferences. Islam commands to abide by the Shariah law (Mansori et al., 2020). Sharia Law also prohibits trading with interest (Riba) (Mansori et al., 2020). For this reason, people who believe in Islam should not receive or give interest (riba). However, compliance with religious rules and religious life may differ among Muslims (Zakaria et al., 2020).

Culture is a feature that distinguishes societies from one another (Hofstede \& McCrae, 2004). As it affects behavior (Akremi \& Smaoui, 2015; Donohue, 2020; Fu et al., 2004), it is also a determinant of ethical evaluations (Oumlil \& Balloun, 2017) and an explanatory of individual behavioral differences (Gaganis et al., 2019). Culture can change over time (Hayton et al., 2002; Yoo \& Donthu, 2005; Yoo, 2009). It affects the perception of the environment and events (Bussoli, 2017; Kreiser et al., 2010; Kanagaretnam et al., 2014). In this context, cultural values have an impact on financial decisions and evaluations (Ashraf et al., 2016; Ashraf \& Arshad, 2017; Ahunov \& Hove, 2020; Bussoli, 2017; Damtsa et al., 2019; Gaganis et al., 2019; Illiashenko \& Laidroo, 2020; Kanagaretnam et al., 2014; Sist \& Kalmi, 2017).

Religion and culture are closely related to each other in terms of their characteristics and effects. People live together in the society. This unity is important in the formation of value judgments and in shaping religious preferences. While religion reflects culture-specific values, cultural values also cause differences in religious beliefs and practices associated with increased socialization (Güngör et al., 2012) and affect ethical evaluations (Kara et al., 2016; Oumlil \& Balloun, 2017). As a result, religiosity is influenced by culture, culture influences religiosity level, and both affect ethical evaluations. For this reason, although a religious person is expected to obey religious rules, it cannot be concluded that $\mathrm{s} / \mathrm{he}$ will never behave unethically (Chan \& Ananthram, 2019).

In this study, the preference of individuals regarding investment alternatives with and without interest in different return scenarios despite the order of interest-free trade and investment, which is one of the basic rules of Islam, was investigated in the context of individual cultural values, religiosity and opinion on interest. The study data were collected in Turkey. Turkey has unique features. Most of its people are Muslim (89.5\%), but they have adopted Western lifestyles and practices (Kara et. al., 2016). It has close cultural ties with Asia and the Middle East but defines itself as a European country (RogersSirin et al., 2017). Especially in recent years, the country has been experiencing rapid changes in the cultural context due to immigration and foreign citizens coming for work (Rogers-Sirin et al., 2017). In this direction, the study was carried out by collecting data from 1934 people, most of whom were young and highly educated. 
The second section of the study is the literature review, the third is the research method and the last section presents the conclusion and discussion.

\section{Literature Review}

Religion is a belief system (Donohue, 2020; Mansori et al., 2020) which shows that people should be valued (Güngör et al., 2012) and allowing the distinction between right and wrong (Oumlil \& Balloun, 2017). The level of commitment to religion was defined as religiosity (Bhuian et al., 2018; Mansori et al., 2020; Tariq et al., 2019; Usman et al., 2017; Zakaria et al., 2020). Religion has psychological and social power (Islam \& Chandrasekaran, 2020). It affects the thoughts, feelings, behaviors and experiences of individuals (Bhuian et al., 2018; Usman et al., 2017). Religiosity is the level of commitment and belief in an individual's religiosity (Mansori et al., 2020; Zakaria et al., 2020). It has two dimensions: internal and external religiosity. While in internal religiosity, there is adherence to religious principles and the desire to serve the religion, in external religiosity there is a utilitarian use for personal interests and social acceptance (Le \& Kieu, 2019; Tariq et al., 2019).

Religiosity is associated with people's values, attitudes and behaviors (Al Balushi et al., 2018; Bhuian et al., 2018; Usman et al., 2017). In this context, just as values, attitudes and behaviors affect commitment to religion, adherence to religion also affects a person's values, attitudes and behaviors. Therefore, different people who believe in the same religion may behave differently (Al Balushi et al., 2018; Bhuian et al., 2018; Mansori et al., 2020; Usman et al., 2017). Although religiosity is a cultural system (Bhuian et al., 2018), studies evaluating religiosity and cultural values are limited (Oumlil \& Balloun, 2017). In this framework, the sub-dimensions of individual cultural values (masculinity, collectivism, power distance and uncertainty avoidance) can be at different levels in people who believe in different religions (Islam \& Chandrasekaran, 2020). People who believe in Islam have the same value (Islam \& Chandrasekaran, 2020). However, having the same values does not mean that they will exhibit the same behavior (Al Balushi et al., 2018; Bhuian et al., 2018; Mansori et al., 2020; Usman et al., 2017). Religiosity is related to every aspect of life as well as financial decisions (Al Balushi et al., 2018; Bhuian et al., 2018; Mansori et al., 2020; Usman et al., 2017). However, the level of commitment to religious rules also affects their level of compliance with religious rules in their financial preferences. In terms of Islam, the most obvious example is the interest. Interest is prohibited according to Sharia law, it is stated that Muslims do not trade with interest. However, studies have reported different results in this context (Al Balushi et al., 2018; Mansori et al., 2020; Usman et al., 2017).

Culture refers to the norms, values, beliefs and behaviors that distinguish groups from each other (Illiashenko \& Laidroo, 2020; Kreiser et al., 2010; Kanagaretnam et al., 2014; Liu et al., 2015). On the other hand, cultural values determine behavior as true/false, ethical/not ethical, acceptable or unacceptable (Ashraf et al., 2016; Ashraf \& Arshad, 2017). In this respect, it is similar to religion. The most common valuation approach to cultural values is Hofstede. Hofstede first measured individual cultural values in four dimensions: power distance, collectivism, uncertainty avoidance, masculinity (Kreiser et al., 2010; Ashraf \& Arshad, 2017), then the long-term orientation was as the fifth dimension (Ashraf \& Arshad, 2017) and later included indulgence as the sixth dimension (Ashraf \& Arshad, 2017; Ahunov \& Hove, 2020; Liu et al., 2015; Sist \& Kalmi, 2017). However, six dimensions are not used in 
finance studies (Sist \& Kalmi, 2017). In this study, following approach of the Yoo and Donthu (2002), culture was evaluated in five dimensions.

Masculinity; refers to gender-related roles and behaviors (Ashraf \& Arshad, 2017; Liu et al., 2015; Rothaermel et al., 2006). The orientation to the masculine is thought to be related to being assertive. It is accepted that people with this feature will prioritize success, status and wealth increase (Akremi \& Smaoui, 2015; Ashraf \& Arshad, 2017; Kreiser et al., 2010; Rothaermel et al., 2006; Zakaria et al., 2020). While Ashraf and Arshad (2017) and Díez-Esteban et al. (2019) indicate a positive relationship between masculinity and risk-taking, Kreiser et al. (2010) point out a negative relationship.

Uncertainty avoidance; refers to the discomfort felt by uncertainty (Ahunov \& Hove, 2020; Ashraf \& Arshad, 2017; Bussoli, 2017; Gaganis et al., 2019; Illiashenko \& Laidroo, 2020; Kanagaretnam et al., 2014; Kreiser et al., 2010; Liu et al., 2015; Rothaermel et al., 2006). People who avoid high levels of uncertainty tend to prefer the precise or predictable and do not seek innovation in their work and life (Bussoli, 2017; Gaganis et al., 2019; Kreiser et al., 2010; Kanagaretnam et al., 2014; Rothaermel et al., 2006). They try to avoid stressfull and anxious situations (Kanagaretnam et al., 2014). Many studies indicate a negative relationship between high uncertainty avoidance and risk-taking (Ashraf et al., 2016; Ashraf \& Arshad, 2017; Bussoli, 2017; Díez-Esteban et al., 2019; Gaganis et al., 2019; Kanagaretnam et al., 2014). On the contrary, Illiashenko and Laidroo (2020) state that these people will take more financial risks to reduce uncertainty.

Power distance; refers to the degree of discomfort with inter-individual hierarchy and power distribution (Kreiser et al., 2010). People with high values in this dimension are satisfied with the high hierarchy, they want the rules to be followed, and they are uncomfortable with innovative thoughts and actions (Kreiser et al., 2010). They do not seek innovation and opportunity because they accept their status and hierarchy (Ashraf \& Arshad, 2017; Gaganis et al., 2019; Rothaermel et al., 2006). In contrast, as the power distance decreases, individual behaviors increase (Kreiser et al., 2010) and in this direction, individuals tend to improve their own situations (Ashraf \& Arshad, 2017). Considering families with high power distance, it is predicted that the financial literacy level of young individuals may be low because the head of the family makes many financial decisions (Ahunov \& Hove, 2020). While some of the studies on literature were stated that power distance and risk-taking are negatively related (Ahunov \& Hove, 2020; Gaganis et al., 2019; Laitinen \& Suvas, 2016), others have mentioned that there is a positive relationship between these variables (Díez-Esteban et al., 2019; Sist \& Kalmi, 2017).

Collectivism; expresses belief and commitment to social solidarity and cooperation (Ashraf \& Arshad, 2017; Bussoli, 2017; Illiashenko \& Laidroo, 2020; Kreiser et al., 2010; Liu et al., 2015; Rothaermel et al., 2006). For individuals with high collectivist values, group success is more important than individual success (Ashraf \& Arshad, 2017; Gaganis et al., 2019; Kreiser et al., 2010; Rothaermel et al., 2006). Therefore, in financial transactions, social welfare and preferences are prioritized rather than individual preferences (Ahunov \& Hove, 2020), and similar preferences are made with other members of the group (Zakaria et al., 2020).

Long-Term Orientation: Focusing on long-term goals rather than short-term (Liu et al., 2015). In other words, it is a reward-oriented behavior to be received in the future (Liu et al., 2015). People with high values in this dimension want to plan for the future and therefore saving is important for them 
(Hofstede et al., 2010). In addition, Lumpkin et al. (2010) stated that firms with a long-term investment orientation tend to take less risk compared to short-term ones. In contrast, Hofstede et al. (2010) stated that short-term oriented investors take more risks for social demands and reputation). In general, this dimension has less studied in financial studies (Ahunov \& Hove, 2020).

\section{Research Method}

\subsection{Research Aim}

This study aims to determine the effect of individual cultural values, religiosity and opinion on interest in preferences of individuals regarding investment alternatives with and without interest. Although it is acknowledged that the preference for investment instruments with interest is related to religiosity and evaluations of the social effects of interest, we think that cultural values are also an important variable. For this reason, we aimed to collect data from Turkey, which has synthesized Eastern and Western cultures, is mostly Muslim but has also adapted its financial markets to Western norms, accepts and interacts with people from a large number of different cultures under the name of immigration from Eastern and Western countries, permanent residence and long-term work.

\section{Research Data}

The data of the study were collected from Turkey through an online survey between May 14, 2020 - 01 June 2020. Graduate students of the Y1ldı Technical University Business Department voluntarily supported data collection and shared the survey link on their social networks. Participation in the survey was voluntary. 1934 people responded to the questionnaire. Four people did not answer demographic questions. However, all participants answered the other questions completely.

Table 1. Demographics Factors

\begin{tabular}{cccc}
\hline \multirow{3}{*}{ Age } & & N & Percent \\
\hline \multirow{3}{*}{ Gender } & $20-30$ Age Group & 1366 & $70,7 \%$ \\
& $31-40$ Age Group & 371 & $19,3 \%$ \\
& $41-50$ Age Group & 119 & $6,2 \%$ \\
\multirow{2}{*}{ Education } & $51+$ Age Group & 74 & $3,8 \%$ \\
& Male & 927 & $48 \%$ \\
& Female & 1003 & $52 \%$ \\
\hline \multirow{2}{*}{ Marital Status } & Primary School & 39 & $2,0 \%$ \\
& High School & 391 & $20,2 \%$ \\
& Undergraduate & 1226 & $63,6 \%$ \\
& Master/Doctorate & 274 & $14,2 \%$ \\
\hline
\end{tabular}

Resource: Composed by Authors

As seen in Table 1, survey participants consist of people who are balanced in terms of gender mostly young people, single and undergraduate or master/doctorate degrees. We have participants who 
are mostly citizens of a Muslim country and have received western-style education and are open to cultural interactions as of their age.

\subsection{Research Variables}

In this study, three independent variables (individual cultural values, religiosity and negative opinion on interest), one dependent variable (investment choice/categorical) and four demographic variables (age, gender, education and marital status) were used. A 20-item scale developed by Yoo and Donthu (2002) was used for the individual cultural values variable in the survey. For the second independent variable, religiosity, a 3-item scale developed by Elçi et al. (2011) was preferred. For the variable of negative opinion on interest, a 5-item scale was developed by us. In addition, all of the scales used for the variables are 5-point Likert type. In this direction, it means 1: Strongly Disagree, ......, 5: Strongly Agree. The number of items and scale information related to the variables is summarized in Table 2.

Table 2. Variables and scales used in research

\begin{tabular}{ccc}
\hline Variables & Items & Scales \\
\hline Individual Cultural Values & 20 & Yoo \& Donthu (2002) \\
Religiosity & 3 & Elçi et al. (2011) \\
Negative Opinion on Interest & 5 & Developed by us \\
\hline
\end{tabular}

Resource: Composed by Authors

\subsection{Analyses}

Discriminant analysis was chosen as the analysis method because the dependent variable was categorical. Since one of the three independent variables preferred in the study was developed by us, exploratory factor analysis was performed for this variable and confirmatory factor analysis was performed for the other two independent variables. The results are reported in Tables 3 and 4.

Table 3. Exploratory Factor Analysis for Negative Opinion on Interest

\begin{tabular}{cc}
\hline \multicolumn{1}{c}{ Items } & $\mathbf{1}$ \\
\hline I don't find it right to invest in interest-earning instruments & 0,761 \\
Interest is responsible for most of the economic problems in our society. & 0,872 \\
Major economic problems have a strong relationship with interest rates. & 0,801 \\
Investment and trade with interest cause economic disaster. & 0,881 \\
Investment and trade with interest should be prohibited & 0,835 \\
Reliability Analysis & 69,062 \\
KMO & 0,886 \\
Bartlett's Test of Sphericity & 0,842 \\
\hline
\end{tabular}

Resource: Composed by Authors

Exploratory factor analysis showed that all five items were collected as a single factor. Kaiser Meyer-Olkin and Bartlett's Test of Sphericity values above the threshold (Field, 2013), which evaluates the suitability of the data for factor analysis, and the reliability analysis value for the factor is also above the threshold (Aren et al., 2021). 
The confirmatory factor analysis results for individual cultural values and religiosity are also reported in Table 4.

Table 4. Confirmatory Factor Analysis for Individual Cultural Values and Religiosity

\begin{tabular}{cccccccc}
\hline CMIN/DF & RMSEA & GFI & IFI & CFI & TLI & NFI & RFI \\
\hline 4,703 & 0,044 & 0,926 & 0,930 & 0,930 & 0,921 & 0,912 & 0,902 \\
\hline
\end{tabular}

Resource: Composed by Authors

As seen in Table 4, all the goodness of fit values are above acceptable values (Aren et al., 2021), and their factor structures were verified.

Since the dependent variable in this study was categorical, a discriminant analysis was conducted (see Table 5). In this way, the effect of individual cultural values, religiosity and opinion on interest in individuals' preferences regarding financial instruments with interest can be measured.

Table 5. Discriminant Analysis for Investment Choices

\begin{tabular}{cccc}
\hline & Wilks' Lambda & F & Sig. \\
\hline Collectivism &, 993 & 6,184 &, 002 \\
Uncertainty Avoidance &, 999 & 1,157 &, 315 \\
Masculinity &, 993 & 6,455 &, 002 \\
Power Distance &, 996 & 4,215 &, 015 \\
Long term orientation &, 998 & 1,582 &, 206 \\
Religiosity &, 946 & 53,129 &, 000 \\
Negative opinion on interest &, 945 & 54,200 &, 000 \\
\hline Function $\quad$ Eigenvalue & Canonical Correlation & Wilks' Lambda & Chi-square \\
\hline 1 & 0,075 & 0,264 & Sig. \\
\hline \multicolumn{7}{c}{ Correctly of classified is 44,2\% } \\
\hline
\end{tabular}

Resource: Composed by Authors

The model established to determine the investment choices of individuals (those who do not want interest return under any circumstances / those who prefer an interest-free investment instrument when the return of an interest-free investment instrument and an interest-bearing investment instrument is equal / those who always prefer an investment instrument with an interest return) is significant at the 0,000 error level and has the power to explain about 7\% (0.2642) of the change. Among the independent variables, collectivism, masculinity, religiosity and negative opinion on interest are significant at the level of 0,01 error and power distance at the level of 0,05 error. The variables that cannot be found significant are uncertainty avoidance and long-term orientation. The correct classification rate of the analysis is also $44.2 \%$.

The equation for discriminant analysis is also significant $\left(\chi^{2}=142,162^{0,000}\right)$ and can be expressed as: Investment Choices $=-3,075+0,129 X_{1}-0,077 X_{2}+0,051 X_{3}-0,150 X_{4}+0,024 X_{5}+0,493 X_{6}+0,529 X_{7}$

$\mathrm{X}_{1}$ : Collectivism, $\mathrm{X}_{2}$ : Uncertainty Avoidance, $\mathrm{X}_{3}$ : Masculinity, $\mathrm{X}_{4}$ : Power Distance, $\mathrm{X}_{5}$ : Long term orientation, $\mathrm{X}_{6}$ : Religiosity, $\mathrm{X}_{7}$ : Negative opinion on interest

The investment alternative to which the value to be calculated using this equation will correspond to is also reported in Table 6 together with its calculations. 
Table 6. Functions at Group Centroids

\begin{tabular}{|c|c|c|c|}
\hline & Centroid & $\begin{array}{c}\text { Equation } \\
\text { Implication }\end{array}$ & Calculation \\
\hline $\begin{array}{l}\text { Those who do not want interest } \\
\text { return under any circumstances }\end{array}$ & 0,288 & $-0,005<\mathrm{D}<0,043$ & $\begin{array}{c}D_{H L I S-M D I S}=\frac{0,288+(-0,202)}{2} \\
=0,043\end{array}$ \\
\hline $\begin{array}{l}\text { Those who prefer an interest- } \\
\text { free investment instrument when } \\
\text { the return of an interest-free } \\
\text { investment instrument and an } \\
\text { interest-bearing investment } \\
\text { instrument are equal }\end{array}$ & $-0,202$ & $\mathrm{D}<-0,250$ & $\begin{aligned} D_{H L I S-N I S} & =\frac{0,288+(-0,298)}{2} \\
& =-0,005\end{aligned}$ \\
\hline $\begin{array}{c}\text { Those who always prefer an } \\
\text { investment instrument with an } \\
\text { interest return }\end{array}$ & $-0,298$ & $-0,250<\mathrm{D}<-0,005$ & $D_{M L I S-N I S}=\frac{-0,202-0,298}{2}=-0,250$ \\
\hline $\begin{array}{r}-\mathbf{0 , 0 0 5}<\mathbf{D}<\mathbf{0 , 0 4 3} \\
-\mathbf{0 , 2 5 0}<\mathbf{D}<-\mathbf{0 , 0 0 5}: \text { Th } \\
\mathbf{D}<-\mathbf{0 , 2 5 0} r \text { Those wh } \\
\text { free investment ins }\end{array}$ & $\begin{array}{l}\text { Those who } \\
\text { e who alway } \\
\text { orefer an in } \\
\text { iment and a }\end{array}$ & $\begin{array}{l}\text { not want interest ret } \\
\text { prefer an investment } \\
\text { est-free investment i } \\
\text { interest-bearing inve }\end{array}$ & $\begin{array}{l}\text { urn under any circumstances } \\
\text { instrument with an interest return } \\
\text { strument when the return of an interest- } \\
\text { tment instrument are equal }\end{array}$ \\
\hline
\end{tabular}

The differentiation of choices for interest-bearing and interest-free investment alternatives according to demographic variables was also investigated using the $\chi 2$ test and presented in Table 7 .

Table 7. Differentiation of Investment Choices According to Demographic Variables

\begin{tabular}{|c|c|c|c|c|c|}
\hline Variable & Sub Groups & $\begin{array}{c}\text { Those who do } \\
\text { not prefer } \\
\text { interest earning }\end{array}$ & $\begin{array}{l}\text { If the same return level, } \\
\text { those who do not prefer } \\
\text { interest earning }\end{array}$ & $\begin{array}{c}\text { Those who do } \\
\text { prefer interest } \\
\text { earning }\end{array}$ & $\chi^{2}$ \\
\hline \multirow{2}{*}{ Gender } & Male & $408(45.4 \%)$ & $202(22.5 \%)$ & $289(32.1 \%)$ & \multirow{2}{*}{4,963} \\
\hline & Female & 477 (48.7\% & $234(23.9 \%)$ & $269(27.4 \%)$ & \\
\hline \multirow{2}{*}{$\begin{array}{c}\text { Marital } \\
\text { Status }\end{array}$} & Single & $253(50.4 \%)$ & $103(20.5 \%)$ & $146(29.1 \%)$ & \multirow{2}{*}{3,799} \\
\hline & Married & $632(45.9 \%)$ & $333(24.2 \%)$ & $412(29.9 \%)$ & \\
\hline \multirow{4}{*}{$\begin{array}{c}\text { Education } \\
\text { Level }\end{array}$} & Primary School & $23(60.5 \%)$ & $9(23.7 \%)$ & $6(15.8 \%)$ & \multirow{4}{*}{$19,097 * *$} \\
\hline & High School & $189(50.3 \%)$ & $96(25.5 \%)$ & $91(24.2 \%)$ & \\
\hline & Undergraduate & $566(47.0 \%)$ & $276(23.0 \%)$ & $360(30.0 \%)$ & \\
\hline & Graduate & $107(40.7 \%)$ & $55(20.9 \%)$ & $101(38.4 \%)$ & \\
\hline \multirow{4}{*}{ Age } & $20-30$ & $656(49.3 \%)$ & $300(22.6 \%)$ & $374(28.1 \%)$ & \multirow{4}{*}{$18,446^{* *}$} \\
\hline & $31-40$ & $141(38.9 \%)$ & $93(25.6 \%)$ & $129(35.5 \%)$ & \\
\hline & $41-50$ & $59(40.8 \%)$ & $29(19.7 \%)$ & $27(39.5 \%)$ & \\
\hline & +51 & $29(45.4 \%)$ & $14(22.5 \%)$ & $28(32.1 \%)$ & \\
\hline
\end{tabular}

Resource: Composed by Authors

The choice of interest-bearing and interest-free investment alternatives does not differ according to gender and marital status. On the other hand, education level and age are important in the differentiation of investment choices. The higher the education level, the higher is the tendency of interest-bearing financial instruments. On the other hand, those in the age groups of 31-40 and 41-50 also prefer interestbearing financial instruments. 
Table 8. Correlations Analysis

\begin{tabular}{cccccccc}
\hline & $\mathbf{1}$ & $\mathbf{2}$ & $\mathbf{3}$ & $\mathbf{4}$ & $\mathbf{5}$ & $\mathbf{6}$ & $\mathbf{7}$ \\
\hline $\mathbf{1}$ & 1 & $0,356^{* *}$ & $0,207^{* *}$ & $0,132^{* *}$ & $0,250^{* *}$ & $0,218^{* *}$ & $0,154^{* *}$ \\
$\mathbf{2}$ & $0,356^{* *}$ & 1 & $0,132^{* *}$ & $0,061^{* *}$ & $0,345^{* *}$ & $0,127^{* *}$ & $0,113^{* *}$ \\
$\mathbf{3}$ & $0,207^{* *}$ & $0,132^{* *}$ & 1 & $0,519^{* *}$ & $0,086^{* *}$ & $0,318^{* *}$ & $0,243^{* *}$ \\
$\mathbf{4}$ & $0,132^{* *}$ & $0,061^{* *}$ & $0,519^{* *}$ & 1 & $0,078^{* *}$ & $0,273^{* *}$ & $0,238^{* *}$ \\
$\mathbf{5}$ & $0,250^{* *}$ & $0,345^{* *}$ & $0,086^{* *}$ & $0,078^{* *}$ & 1 & $0,191^{* *}$ & $0,048^{*}$ \\
$\mathbf{6}$ & $0,218^{* *}$ & $0,127^{* *}$ & $0,318^{* *}$ & $0,273^{* *}$ & $0,191^{* *}$ & 1 & $0,585^{* *}$ \\
$\mathbf{7}$ & $0,154^{* *}$ & $0,113^{* *}$ & $0,243^{* *}$ & $0,238^{* *}$ & $0,048^{*}$ & $0,585^{* *}$ & 1 \\
\hline
\end{tabular}

1: Collectivism; 2: Power Distance; 3: Masculinity; 4: Uncertainty Avoidance; 5: Long-Term Orientation; 6: Religiosity; 7: Negative opinion on interest

Resource: Composed by Authors

Finally, correlation analysis was performed for the independent variables, and the results are reported in Table 8. Collectivism, uncertainty avoidance, masculinity, power distance and long-term orientation are positively related to both religiosity and negative opinions on interest.

\section{Conclusion and Discussion}

In this study, the effect of individual cultural values, religiosity and negative opinion on interest in interest-bearing and interest-free investment choices was investigated. Collectivism requires observing the social good. Islam also recommends that all Muslims are brothers and sisters and are in solidarity. The Sharia law prohibits interest. In this study, we found a positive relationship between collectivism and religiosity and negative opinion on interest, and we determined that collectivism is an important variable in choosing interest-free financial instruments. The masculine tendency aspires to be respected in society. In a predominantly Muslim country, religiosity increases respect among religious people. In this context, a positive relationship was found between masculinity and religiosity and negative opinion on interest, and it was determined that masculinity was an important variable in choosing interest-free financial instruments. Power distance, the third dimension of individual cultural values, points out accepting unequal power distance and at the same time obeying the rules. Therefore, people who follow Sharia law are expected to have a higher level of religiosity and have a negative opinion on interest. Our findings support these predictions. Power distance is also an important variable in choosing interest-free financial instruments. On the other hand, although we found a positive relationship between uncertainty avoidance and long-term orientation and religiosity and negative opinion on interest, we could not provide strong evidence that they could be an important variable in choosing interest-free financial instruments.

Gender and marital status are not determining variables when choosing non-interest financial instruments. On the other hand, as the education level rises, interest-bearing financial instruments tend t1 increase. Similarly, individuals in the age groups 31-40 and 41-50 also tend to choose interest-bearing financial instruments more than those in other age groups. In conclusion, this research was carried out with data collected from a country like Turkey, which adopts a democratic secular administration in accordance with Western norms and is mostly young and highly educated. At the same time, in recent years, Turkey has been receiving a high rate of immigration from various Muslim countries, especially Syria, accepting people coming from countries such as Azerbaijan, Turkmenistan, Georgia and Armenia with long-term work permits and members of different countries residing in the country through direct 
investment or marriage from European countries. This situation affects the cultural values of the country, affects the religiosity understanding of the people, and changes the evaluations regarding interest due to the pressure of economic conditions from time to time. This study under these conditions is very important in terms of showing that cultural values and religiosity are important in investment choices and that young and well-educated individuals have different interest sensitivities than the rest of the society.

\section{References}

Ahunov, M., \& Hove, L. V. (2020). National culture and financial literacy: international evidence. Applied Economics, 52(21), 2261-2279. https://doi.org/10.1080/00036846.2019.1688241

Akremi, A., \& Smaoui, F. (2015). Socially Responsible Consumption in Emerging Markets: Do Cultural Values And Religiosity Matter? Conference: 8th Annual Conference of the EuroMed-Academy-ofBusiness Location: Verona, Italy, Sep 16-18, 2015, Innovation, Entrepreneurship and Sustainable Value Chain In A Dynamic Environment (pp. 69-83).

Al Balushi, Y., Locke, S., \& Boulanoua, Z. (2018). Islamic financial decision-making among SMEs in the Sultanate of Oman: An adaption of the theory of planned behavior. Journal of Behavioral and Experimental Finance, 20, 30-38. https://doi.org/10.1016/j.jbef.2018.06.001

Aren, S., Hamamc1, H. N., \& Özcan, S. (2021). Moderation Effect of Pleasure Seeking and Loss Aversion in the Relationship between Personality Traits and Risky Investment Intention. Kybernetes, 50(12), 3305-3330. https://doi.org/10.1108/K-05-2020-0278

Ashraf, B. N., \& Arshad, S. (2017). Foreign bank subsidiaries' risk-taking behavior: Impact of home and host country national culture. Research in International Business and Finance, 41, 318-335. https://doi.org/10.1016/j.ribaf.2017.04.039

Ashraf, B. N., Zheng, C., \& Arshad, S. (2016). Effects of national culture on bank risk-taking behavior. Research in International Business and Finance, 37, 309-326. https://doi.org/10.1016/j.ribaf.2016.01.015

Bhuian, S. N., Sharma, S. K., Butt, I., \& Ahmed, Z. U. (2018). Antecedents and pro-environmental consumer behavior (PECB): the moderating role of religiosity. Journal of Consumer Marketing, 35(3), 207-299. https://doi.org/10.1108/JCM-02-2017-2076

Bussoli, C. (2017). Influence of National Culture on Bank Risk-taking in the European System, Risk Culture in Banking. In A. Carretta, F. Fiordelisi, \& P. Schwizer (Eds.), Studies in Banking and Financial Institutions (pp. 215-239). Palgrave Macmillan. https://doi.org/10.1007/978-3-31957592-6_10

Chan, C., \& Ananthram, S. (2019). Religion-Based Decision Making in Indian Multinationals: A Multifaith Study of Ethical Virtues and Mindsets. Journal of Business Ethics, 156(3), 651-677. https://doi.org/10.1007/s10551-017-3558-7

Damtsa, S. M., Milidonis, A., \& Stathopoulos, K. (2019). National culture and bank risk-taking. Journal of Financial Stability, 40, 132-143. https://doi.org/10.1016/j.jfs.2017.08.007

Díez-Esteban, J. M., Farinha, J. B., \& García-Gómez, C. D. (2019). How does national culture affect corporate risk-taking? Eurasian Business Review, 9, 49-68. https://doi.org/10.1007/s40821-0180105-0

Donohue, D. K. (2020). Religiosity and Multicultural Experiences Predict Cultural Values in College Students. Current Psychology, 1-10. https://doi.org/10.1007/s12144-019-00590-6

Elçi, M., Şener, İ., \& Alpkan, L. (2011). The Impact of Morality and Religiosity of Employees on Their Hardworking Behavior. 7th International Strategic Management Conference, Procedia Social and Behavioral Sciences, 24, 1367-1377. https://doi.org/10.1016/j.sbspro.2011.09.135

Field, A. (2013). Discovering Statistics Using IBM SPSS Statistics (4 ${ }^{\text {th }}$ ed.). Transcontinental Printing Inc. Fu, P. P., Kennedy, J. C., Tata, J., Yukl, G., Bond, M. H., Peng, T. K., Srinivas, E. S., Howell, J. P., Prieto, L., Koopman, P. L., Boonstra, J. J., Pasa, S., Lacassagne, M. F., Higashide, H., \& Cheosakul, A. (2004). The impact of societal cultural values and individual social beliefs on the 
perceived effectiveness of managerial influence strategies: a meso approach. Journal of International Business Studies, 35, 284-305. https://doi.org/10.1057/palgrave.jibs. 8400090

Gaganis, C., Hasan, I., Papadimitri, P., \& Tasiou, M. (2019). National culture and risk-taking: Evidence from the insurance industry. Journal of Business Research, 97, 104-116. https://doi.org/10.1016/j.jbusres.2018.12.037

Güngör, D., Bornstein, M. H., \& Phalet, K. (2012). Religiosity, values, and acculturation: A study of Turkish, Turkish-Belgian, and Belgian adolescents. International Journal of Behavioral Development, 36(5), 367-373. https://doi.org/10.1177/0165025412448357

Hayton, J. C., George, G., \& Zahra, S. A. (2002). National Culture and Entrepreneurship: A Review of Behavioral Research. Entrepreneurship Theory and Practice, 26(4), 33-52. https://doi.org/10.1177/104225870202600403

Hofstede, G., \& McCrae, R. R. (2004). Personality and Culture Revisited: Linking Traits and Dimensions of Culture", Cross-Cultural Research, 38(1), 52-88. https://doi.org/10.1177/1069397103259443

Hofstede, G., Hofstede, G. J., \& Minkov, M. (2010). Cultures and Organizations Software of the Mind Intercultural Cooperation and Its Importance for Survival ( $3^{\text {rd }}$ ed.). The McGraw-Hill Companies.

Illiashenko, P., \& Laidroo, L. (2020). National culture and bank risk-taking: Contradictory case of individualism. Research in International Business and Finance, 51, 101069, 1-15. https://doi.org/10.1016/j.ribaf.2019.101069

Islam, T., \& Chandrasekaran, U. (2020). Religiosity and consumer decision making styles of young Indian Muslim consumers. Journal of Global Scholars of Marketing, 30(2), 147-169. https://doi.org/10.1080/21639159.2019.1679031

Kanagaretnam, K., Lim, C. Y., \& Lobo, G. J. (2014). Influence of National Culture on Accounting Conservatism and Risk-Taking in the Banking Industry. The Accounting Review, 89(3), 11151149. https://doi.org/10.2308/accr-50682

Kara, A., Rojas-Méndez, J. I., \& Turan, M. (2016). Ethical Evaluations of Business Students in an Emerging Market: Effects of Ethical Sensitivity, Cultural Values, Personality, and Religiosity. Journal of Academic Ethics, 14, 297-325. https://doi.org/10.1007/s10805-016-9263-9

Kreiser, P. M., Marino, L. D., Dickson, P., \& Weaver, K. M. (2010). Cultural Influences on Entrepreneurial Orientation: The Impact of National Culture on Risk Taking and Proactiveness in SMEs", Entrepreneurship: Theory and Practice, 34(5), 959-983. https://doi.org/10.1111/j.15406520.2010.00396.x

Laitinen, E. K., \& Suvas, A. (2016). Financial distress prediction in an international context: Moderating effects of Hofstede's original cultural dimensions. Journal of Behavioral and Experimental Finance, 9, 98-118. https://doi.org/10.1016/j.jbef.2015.11.003

Le, T. D., \& Kieu, T. A. (2019). Ethically minded consumer behaviour in Vietnam: An analysis of cultural values, personal values, attitudinal factors and demographics. Asia Pacific Journal of Marketing and Logistics, 31(3), 609-626. https://doi.org/10.1108/APJML-12-2017-0344

Liu, J., Meng, F., \& Fellows, R. (2015). An exploratory study of understanding project risk management from the perspective of national culture. International Journal of Project Management, 33, 564575. https://doi.org/10.1016/j.ijproman.2014.08.004

Lumpkin, G. T., Brigham, K. H., \& Moss, T. W. (2010). Long-term orientation: Implications for the entrepreneurial orientation and performance of family businesses. Entrepreneurship \& Regional Development: An International Journal, 22(3-4), 241-264. https://doi.org/10.1080/08985621003726218

Mansori, S., Safari, M., \& Mohd Ismail, Z. M. (2020). An analysis of the religious, social factors and income's influence on the decision making in Islamic microfinance schemes. Journal of Islamic Accounting and Business Research, 11(2), 361-376. https://doi.org/10.1108/JIABR-03-2016-0035

Oumlil, A. B., \& Balloun, J. L. (2017). Cultural variations and ethical business decision making: a study of individualistic and collective cultures. Journal of Business \& Industrial Marketing, 32(7), 889900. https://doi.org/10.1108/JBIM-08-2016-0194

Rogers-Sirin, L., Yanar, C., Yüksekbaş, D., Senturk, M. I., \& Sirin, S. (2017). Religiosity, Cultural Values, and Attitudes Toward Seeking Psychological Services in Turkey. Journal of CrossCultural Psychology, 48(10), 1587-1604. https://doi.org/10.1177/0022022117732532 
Rothaermel, F. T., Kotha, S., \& Steensma, H. K. (2006). International Market Entry by U.S. Internet Firms: An Empirical Analysis of Country Risk, National Culture, and Market Size. Journal of Management, 32(1), 56-82. https://doi.org/10.1177/0149206305277793

Sist, F., \& Kalmi, P. (2017). Risk-Taking of the European Banks in CEECs: The Role of National Culture and Stake Vs Shareholder View, Risk Culture in Banking, Palgrave Macmillan Studies in Banking and Financial Institutions (pp. 241-257). Palgrave Macmillan, Cham. https://doi.org/10.1007/9783-319-57592-6 11

Tariq, S., Ansari, N. G., \& Alvi, T. H. (2019). The impact of intrinsic and extrinsic religiosity on ethical decision-making in management in a non-Western and highly religious country. Asian Journal of Business Ethics, 8, 195-224. https://doi.org/10.1007/s13520-019-00094-3

Usman, H., Tjiptoherijanto, P., Balqiah, T. E., \& Agung, I. G. N. (2017). The role of religious norms, trust, importance of attributes and information sources in the relationship between religiosity and selection of the Islamic bank. Journal of Islamic Marketing, 8(2), 158-186. https://doi.org/10.1108/JIMA-01-2015-0004

Yoo, B. (2009). Cross-National Invariance of The Effect of Personal Collectivistic Orientation on Brand Loyalty and Equity: The United States Versus South Korean Consumers. Asia Pacific Journal of Marketing and Logistics, 21(1), 41-57. https://doi.org/10.1108/13555850910926236

Yoo, B., \& Donthu, N. (2002). The Effects of Marketing Education and Individual Cultural Values on Marketing Ethics of Students. Journal of Marketing Education, 24(2), 92-103. https://doi.org/10.1177/0273475302242002

Yoo, B., \& Donthu, N. (2005). The effect of personal cultural orientation on consumer ethnocentrism: Evaluations and behaviors of U.S. consumers toward Japanese products. Journal of International Consumer Marketing, 18(1-2), 7-44. https://doi.org/10.1300/J046v18n01_02

Zakaria, N., Wan-Ismail, W.-N. A., \& Abdul-Talib, A. N. (2020). Seriously, conspicuous consumption? The impact of culture, materialism and religiosity on Malaysian Generation Y consumers' purchasing of foreign brands. Asia Pacific Journal of Marketing and Logistics, 33(2), 526-560. https://doi.org/10.1108/APJML-07-2018-0283 